\title{
inu \\ Obstructive Sleep Apnea: Another Condition to Screen for in Women with Infertility
}

\author{
Leeann M. Bui ${ }^{1}{ }^{\circledR}$, Mihaela Bazalakova ${ }^{2}$, Kathleen M. Antony ${ }^{1}$ and Laura G. Cooney ${ }^{1, *}$ \\ 1 Department of Obstetrics and Gynecology, University of Wisconsin School of Medicine and Public Health, \\ Madison, WI 53562, USA; leeann.bui@wisc.edu (L.M.B.); kantony@wisc.edu (K.M.A.) \\ 2 Department of Neurology, Wisconsin Sleep, University of Wisconsin School of Medicine and Public Health, \\ Madison, WI 53562, USA; bazalakova@neurology.wisc.edu \\ * Correspondence: lcooney2@wisc.edu; Tel.: +1-(608)-824-6160
}

check for updates

Citation: Bui, L.M.; Bazalakova, M.; Antony, K.M.; Cooney, L.G.

Obstructive Sleep Apnea: Another Condition to Screen for in Women with Infertility. Women 2022, 2, 56-63. https://doi.org/10.3390/ women 2010006

Academic Editors:

Tomer Avidor-Reiss, Samantha Beth Schon, Angela K. Lawson and Deborah Ikhena-Abel

Received: 20 December 2021 Accepted: 18 February 2022 Published: 25 February 2022

Publisher's Note: MDPI stays neutral with regard to jurisdictional claims in published maps and institutional affiliations.

Copyright: (C) 2022 by the authors. Licensee MDPI, Basel, Switzerland. This article is an open access article distributed under the terms and conditions of the Creative Commons Attribution (CC BY) license (https:// creativecommons.org/licenses/by/ $4.0 /)$.

\begin{abstract}
Women with obstructive sleep apnea (OSA) are at increased risk of poor pregnancy outcomes such as fetal growth restriction, hypertensive disorders of pregnancy, and gestational diabetes mellitus. Given this increased risk, we aimed to study the screening prevalence of OSA in women seeking fertility treatment. We performed a cross sectional study of patients presenting to a university-affiliated fertility clinic between March-April 2021. Patients were asked to complete OSA screening (STOP-BANG), anxiety screening (GAD-7), and depression screening (PHQ-2) questionnaires. 107 women completed the surveys. Mean age was 35.1 years and mean body mass index (BMI) was $25.7 \mathrm{~kg} / \mathrm{m}^{2}$. Nine $(8.4 \%)$ women screened positive for OSA using the STOP-BANG screening tool. Women who screened positive for OSA were more likely to be older (37.8 years vs. 34.7 years, $p=0.02$ ) and have a higher BMI $\left(42.6 \mathrm{~kg} / \mathrm{m}^{2}\right.$ vs. $\left.27.4 \mathrm{~kg} / \mathrm{m}^{2}, p<0.001\right)$. Women who screened positive for OSA were also more likely to screen positive for mild-severe depressive symptoms $(22.2 \% \mathrm{vs} .3 .1 \%$, $p=0.006)$ and mild-severe anxiety $(66.7 \%$ vs. $21.4 \%, p=0.003)$ symptoms. $24.3 \%$ of the population had polycystic ovary syndrome (PCOS). Women with PCOS were more likely to screen positive for OSA $(19.2 \%$ vs. $4.9 \%$; $p=0.04)$. Despite this being a low-risk population of young women seeking fertility evaluation or treatment, $8 \%$ screened positive for OSA. Given the association between OSA and adverse pregnancy outcomes, our results underline the need to screen women seeking fertility treatment.
\end{abstract}

Keywords: obstructive sleep apnea; sleep disturbance; infertility; fertility; pregnancy; depression; anxiety

\section{Introduction}

Approximately $47 \%$ of pregnant women have at least one pre-specified pregnancy complication, such as fetal abnormalities, preterm delivery, hypertensive disorders, or gestational diabetes [1]. These pregnancy complications are associated with higher adjusted incremental health care costs, with hypertension and diabetes diagnoses increasing costs by approximately $\$ 6000$ and $\$ 5000$, respectively [1]. In women who seek treatment for infertility, preconception counselling and testing is often performed to identify women at high risk for pregnancy complications and treat any risk factors ahead of time. However, given the young age of most women presenting for fertility care, screening for obstructive sleep apnea (OSA) is often overlooked.

Obstructive sleep apnea, the most common sleep breathing disorder, is characterized by recurrent episodes of partial or complete obstruction of the upper airway leading to reduced or absent breathing during sleep [2]. OSA is associated with an increased risk for several medical comorbidities including hypertension, cardiovascular disease, heart failure, neuropsychiatric dysfunction, and type 2 diabetes [3-16], and affects approximately $9 \%$ of reproductive aged women and between $4-32 \%$ of uncomplicated pregnancies [17-20]. 
Pregnant women may also be predisposed to OSA due to hormonal and physical changes throughout pregnancy such as increased body weight and upper airway edema [21] Multiple studies have demonstrated that even "mild" OSA by traditional diagnostic criteria is an independent risk factor for pregnancy-related complications such as hypertensive disorders of pregnancy (early-pregnancy: OR 1.46, 95\% CI 0.91-2.32; mid-pregnancy: OR 1.73 , 95\% CI 1.19-2.52), preeclampsia (early-pregnancy: OR 1.94, 95\% CI 1.07-3.51; mid-pregnancy: OR 1.95, 95\% CI 1.18-3.23), gestational diabetes (early-pregnancy: OR $3.47,95 \%$ CI 1.95-6.91; mid-pregnancy: OR $2.79,95 \%$ CI 1.63-4.77), and, possibly, poor neonatal outcomes $[20,22-28]$. The precise mechanism by which sleep disorders adversely influence pregnancy outcomes remains unclear. However, some hypothesize that poor sleep quality increases intravascular inflammation, oxidative stress, and endothelial cell dysfunction [2,29] which are central to the development of preeclampsia [30-33]. Despite this established association between OSA and adverse pregnancy outcomes, little research has examined OSA's association with infertility.

To date, the majority of evidence for the association between sleep disturbances and diminished reproductive capacity has been described in the context of shiftwork with circadian misalignment [34,35]. Given the increased risk of poor pregnancy outcomes in women with OSA, we aimed to study the prevalence of OSA in women seeking fertility treatment.

\section{Results}

Between March and June 2021, 107 women completed screenings for OSA (STOPBANG), anxiety (Generalized Anxiety Disorder-7, GAD-7), and depression (Patient Health Questionnaire-2, PHQ-2) during new patient or return clinic visits at Generations Fertility Care in Madison, WI. The mean age was $34.9( \pm 4.0)$ years, and the mean body mass index (BMI) was $28.7( \pm 8.2) \mathrm{kg} / \mathrm{m}^{2}$. Most women were married $(92.5 \%)$, Caucasian $(88.8 \%)$, and did not report a history of depression $(76.6 \%)$ or anxiety $(64.5 \%)$. Two women reported a previous history of OSA (1.9\%) but only one reported using a continuous positive airway pressure (CPAP) machine. Six women (4.7\%) screened positive for mild-severe depressive symptoms and 27 women $(25.2 \%)$ screened positive for mild-severe anxiety symptoms.

Nine women (8.4\%) screened positive for intermediate-high risk OSA. Women who screened positive for OSA were more likely to be Caucasian, married, older (37.8 years vs. 34.7 years, $p=0.02)$, have a higher BMI $\left(42.6 \mathrm{~kg} / \mathrm{m}^{2}\right.$ vs. $\left.27.4 \mathrm{~kg} / \mathrm{m}^{2}, p<0.001\right)$ and have a history of depression $(77.8 \%$ vs. $18.4 \%, p<0.001)$ or anxiety $(77.8 \%$ vs. $31.6 \%, p=0.006)$ compared to those who screened negative (Table 1). All nine patients who screened positive for OSA had a BMI $>35 \mathrm{~kg} / \mathrm{m}^{2}$ (versus $12.2 \%$ of those who screened negative; $p<0.001$ ). Women who screened positive for OSA were also more likely to screen positive for mild depressive symptoms (22.2\% vs. 3.1\%, $p=0.009)$ with a higher PHQ2 score (median: 2 (IQR: $0-2$ ) vs. 0 (IQR: $0-1$ ); $p=0.005$ ). They were also more likely to screen positive for mild and moderate anxiety (mild: $44.4 \%$ vs. $17.4 \%$; moderate: $22.2 \%$ vs. $4.1 \% ; p=0.009$ ) with a higher GAD7 score (median: 5 (IQR: 2-8) vs. 2 (IQR: 0-4); $p=0.04$ ).

Table 1. Comparison of demographics of participants screening positive versus negative for OSA.

\begin{tabular}{cccc}
\hline & No OSA & OSA & $p$ Value \\
\hline Total & $98(91.6)$ & $9(8.4)$ & \\
\hline Mean age (years) (sd) & $34.7(3.8)$ & $37.8(4.4)$ & 0.02 \\
\hline Age categories (years) & & & \\
$26-30$ & $22(22.5)$ & $1(11.1)$ & \\
$31-35$ & $41(41.8)$ & $1(11.1)$ & 0.07 \\
$36-40$ & $29(29.6)$ & $5(55.6)$ & \\
$41-45$ & $6(6.1)$ & $2(22.2)$ & \\
\hline
\end{tabular}


Table 1. Cont.

\begin{tabular}{|c|c|c|c|}
\hline & No OSA & OSA & $p$ Value \\
\hline \multicolumn{4}{|l|}{ Race } \\
\hline White & $84(85.7)$ & $8(89.9)$ & \multirow{3}{*}{0.02} \\
\hline Black or African American & $0(0)$ & $1(12.5)$ & \\
\hline Other & $14(14.3)$ & $0(0)$ & \\
\hline Mean BMI $\left(\mathrm{kg} / \mathrm{m}^{2}\right)(\mathrm{sd})$ & $27.4(7.3)$ & $42.6(4.5)$ & $<0.001$ \\
\hline \multicolumn{4}{|l|}{ BMI $\left(\mathrm{kg} / \mathrm{m}^{2}\right)$} \\
\hline Underweight $(<18.5)$ & $6(6.1)$ & $0(0)$ & \multirow{6}{*}{$<0.001$} \\
\hline Normal weight (18.5-24.9) & $42(42.9)$ & $0(0)$ & \\
\hline Overweight (25-29.9) & $22(22.5)$ & $0(0)$ & \\
\hline Obese Class I (30.0-34.9) & $16(16.3)$ & $0(0)$ & \\
\hline Obese Class II (35.0-39.9) & $5(5.1)$ & $3(33.2)$ & \\
\hline Obese Class III (>40.0) & $7(7.1)$ & $6(66.7)$ & \\
\hline \multicolumn{4}{|l|}{ Marital status } \\
\hline Single & $0(0)$ & $2(22.2)$ & \multirow{5}{*}{$<0.001$} \\
\hline Married & $92(93.4)$ & $7(77.8)$ & \\
\hline Separated & $1(1.0)$ & $0(0)$ & \\
\hline Divorced & $1(1.0)$ & $0(0)$ & \\
\hline Partner & $4(4.1)$ & $0(0)$ & \\
\hline \multicolumn{4}{|l|}{ History of OSA } \\
\hline No & $98(100)$ & $7(77.8)$ & \multirow{2}{*}{$<0.001$} \\
\hline Yes & $0(0)$ & $2(22.2)$ & \\
\hline \multicolumn{4}{|l|}{ History of depression } \\
\hline No & $80(81.6)$ & $2(22.2)$ & \multirow[b]{2}{*}{$<0.001$} \\
\hline Yes & $18(18.4)$ & $7(77.8)$ & \\
\hline Median PHQ2 score (IQR) & $0(0-2)$ & $2(1-4)$ & 0.005 \\
\hline \multicolumn{4}{|l|}{ Screen positive for depression } \\
\hline PHQ2: 0-2 (negative depression score) & $95(96.9)$ & $7(77.8)$ & \multirow{2}{*}{0.009} \\
\hline PHQ2: 3 or more (positive depression score) & $3(3.1)$ & $2(22.2)$ & \\
\hline \multicolumn{4}{|l|}{ History of anxiety } \\
\hline No & $67(68.4)$ & $2(22.2)$ & \multirow{2}{*}{0.006} \\
\hline Yes & $31(31.6)$ & $7(77.8)$ & \\
\hline Median GAD7 score (IQR) & $5(2-8)$ & $2(0-4)$ & 0.04 \\
\hline \multicolumn{4}{|l|}{ Anxiety } \\
\hline GAD7: 0-4 (minimal anxiety) & $77(78.6)$ & $3(33.3)$ & \multirow{4}{*}{0.006} \\
\hline GAD7: 5-9 (mild anxiety) & $17(17.4)$ & $4(44.4)$ & \\
\hline GAD7: 10-14 (moderate anxiety) & $4(4.1)$ & $2(22.2)$ & \\
\hline GAD7: >15 (severe anxiety) & $0(0)$ & $0(0)$ & \\
\hline
\end{tabular}

Categorical variables presented as $n(\%)$. Continuous variables are calculated using $t$-test or Wilcoxon rank sum as appropriate and presented as mean (standard deviation (SD)) or median (IQR (interquartile range)).

In addition, 45 women (42.1\%) reported at least one other sleep related symptom including 13 women (12.2\%) who reported snoring loudly; 35 women (32.7\%) who reported feeling tired, fatigued, or sleepy during the daytime; and five women (4.7\%) who reported someone observe that they stopped breathing, choked, or gasped during their sleep. Similar to those who screened positive for OSA, those who reported another sleep related symptom were more likely to have a higher BMI $\left(31.1 \mathrm{~kg} / \mathrm{m}^{2}\right.$ vs. $\left.26.2 \mathrm{~kg} / \mathrm{m}^{2} ; p=0.002\right)$ and more likely to have mild or moderate anxiety (mild: $31.1 \%$ vs. $11.3 \%$; moderate: $11.1 \%$ vs. $1.6 \%$; $p=0.002$ ) than those who did not have a sleep related symptom. If only women with a $\mathrm{BMI}>35 \mathrm{~kg} / \mathrm{m}^{2}$ were screened for OSA, $66.7 \%$ of women with a sleep related symptom and $66.7 \%$ of women with anxiety would have been missed.

Twenty-six women had polycystic ovary syndrome (PCOS) $(24.3 \%)$ and nine had a history of chronic hypertension (8.4\%). Women with PCOS were more likely to screen 
positive for OSA than women without PCOS $(19.2 \%$ vs. $4.9 \%$; $p=0.04)$. Similarly, women with a history of chronic hypertension were more likely to screen positive for OSA ( $44.4 \%$ vs. $5.1 \% ; p=0.003$ ).

\section{Discussion}

In this observational study, we found that approximately $8 \%$ of young women seeking infertility evaluation screened positive for OSA using the STOP-BANG screening questionnaire. We also found that women who screened positive for OSA were also more likely to screen positive for mild depression and mild-severe anxiety.

Despite the growing data on the negative impacts of OSA in pregnancy, there is minimal data on the prevalence of OSA in women with infertility. In a secondary analysis of two large randomized controlled trials evaluating fertility treatment options in women with PCOS and unexplained infertility, women with PCOS had higher rates of both selfreported diagnosis of OSA ( $7.1 \%$ vs. $1.6 \%, p<0.002)$ and "clinical symptoms of obstructive sleep apnea" defined as having a sleep duration of $<6 \mathrm{~h}$ and snoring $(4.1 \%$ vs. $0.9 \%$, $p<0.001$ ) [36]. However, no study has performed overnight polysomnography on women with infertility.

The importance of OSA screening in women seeking fertility treatment is highlighted by the established association between OSA and pregnancy complications in recent studies. One of the most comprehensive studies, a sub-study of the Nulliparous Pregnancy Outcomes Study Monitoring Mothers-to-be (nuMoM2b), recruited 3702 healthy pregnant women to undergo objective, overnight-in home assessments of sleep-disordered breathing. They found that women with OSA had an increased odds of preeclampsia in early (OR: 1.94, 95\% CI 1.07-3.51) and mid- (OR: 1.95, 95\% CI 1.18-3.23) pregnancy, hypertensive disorders of pregnancy in early (OR: 1.46, 95\% CI 0.91-2.32) and mid- (OR: 1.73, 95\% CI 1.19-2.52) pregnancy, and gestational diabetes mellitus (GDM) in early (OR: 3.47, 95\% CI 1.95-6.19) and mid- (OR: 2.79, 95\% CI 1.63-4.77) pregnancy [20].

Interestingly, we also found that $42 \%$ of women in our study reported a sleep related symptom such as snoring, daytime sleepiness, or witnessed apneic events. Females have been shown to be more symptomatic with lower apnea-hypopnea scores compared to males [37]. Women may also display upper airway restriction rather than overt obstruction on testing, and may report fatigue, rather than sleepiness, mood disorders, or insomnia as their main complaints [38,39]. As a consequence of these differences in clinical presentation and diagnostic criteria, females with sleep disordered breathing are likely underdiagnosed and undertreated compared to males [40,41].

Depression and OSA are two associated comorbidities with many overlapping symptoms such as disturbed sleep, weight gain, restlessness, and fatigue [41]. The relationship between OSA and depression is complex. Some researchers hypothesize that sleep fragmentation and hypoxemia seen in OSA may play a large role in influencing depressive symptoms $[42,43]$. Other researchers have found that continuous positive airway pressure therapy (CPAP) use among patients with OSA was associated with improvements in both depressive and anxiety symptoms [43]. It is established that women with infertility have an increased risk of depression and anxiety [44-47]. By identifying and treating women with infertility who also screen positive for OSA, we have the opportunity to improve mood symptoms in this population.

The association between PCOS and screening positive for OSA in our population was not surprising. In a recent meta-analysis, reproductive aged women with PCOS had a pooled prevalence of OSA of 32\% (95\% CI 13-55\%; 8 studies), and were 9.7 times more likely to have OSA than women without PCOS (95\% CI: 2.76-34.41); however, not all studies controlled for BMI [48].

In our population, all women who screened positive for sleep apnea had a BMI $>35 \mathrm{~kg} / \mathrm{m}^{2}$, raising the question as to whether OSA screening should be targeted to the obese population. Interestingly, we found that if screening was thus limited, we would have missed two-thirds of women with a sleep-related symptom such as snoring 
and two-thirds of women with anxiety symptoms. Thus, although we would encourage screening all women with infertility for sleep apnea, the clear link between obesity and sleep apnea cannot be ignored. Studies demonstrate that overweight/obesity negatively impacts fertility with an increased time to conception, increased rates of anovulation, and decreased responsiveness to ovulation induction medication [49]. Although the effectiveness of lifestyle (LS) interventions prior to fertility treatment in the general population is mixed [50,51], overweight/obese women with PCOS may have a potential fertility benefit of weight loss prior to using oral ovulation induction medications [52,53]. In addition, weight loss in women seeking pregnancy is also recommended to decrease risks of maternal and fetal complications during pregnancy [49]. Our study highlights that increased risk of sleep apnea in women with obesity seeking pregnancy should also be considered when counselling women on weight loss.

This study has several strengths including the addition of depression/anxiety screening, which was not included in the previous study evaluating OSA prevalence in women with infertility. However, this study and the questionnaires have several limitations. STOPBANG serves primarily as a clinical instrument to screen for OSA with positive screens requiring additional confirmatory testing with polysomnography. Second, risk of OSA increases with age and it is more common in men compared to women, thus most screening tools are biased towards detection of OSA in older men. In our study, we only evaluated young women but still used the conventional cut-off of $\geq 3$ to indicate a screen-positive. However, out of the eight questions in the STOP-BANG questionnaire, three are automatically negative or unknown for young reproductive-aged women: (1) "Are you male?", (2) "Are you older than 50 years?", and (3) "Is your neck circumference greater than $40 \mathrm{~cm}$ ?"often unknown in women in contrast to men who may know their neck circumference to aid in dress shirt sizing. Although the questionnaire successfully accounts for the male predominance of OSA, it oversimplifies the disease gender discrepancies, thus potentially under-diagnosing and under-treating OSA in women during the early stage of the disease. More studies are needed to determine if women who have a sleep related symptom (over $40 \%$ of our population) have sleep study-diagnosed OSA or any adverse pregnancy outcomes.

\section{Materials and Methods}

\subsection{Study Design}

We conducted a cross-sectional study at Generations Fertility Care, the reproductive endocrinology clinic associated with the University of Wisconsin, Madison. All female patients attending a new patient fertility evaluation or a return patient follow-up visit between March-April 2021 were included. There were no exclusion criteria. This study was granted exemption from review by the UW-Madison Institutional Review Board Committee as a quality improvement project.

\subsection{Questionnaires}

The STOP-BANG questionnaire is a validated questionnaire to screen for OSA consisting of eight questions asking about loud snoring, daytime fatigue, witnessed apneas, history of hypertension, age more than 50 years, BMI more than $35 \mathrm{~kg} / \mathrm{m}^{2}$, neck circumference more than $40 \mathrm{~cm}$, and male gender [54]. Neck circumference was not routinely measured as many visits were conducted via telemedicine. Screening positive for intermediate-high OSA risk status was determined by patients answering "yes" to three or more of the questions.

Due to the known relationship of mood disorders with both infertility and OSA, PHQ-2 and GAD-7 were used to screen for depressive and anxiety symptoms, respectively. PHQ-2 scores greater than or equal to three were considered a positive depression screen. GAD-7 scores between 1-4 were considered "minimal anxiety," scores 5-9 "mild anxiety," scores 10-14 "moderate anxiety," and scores greater than 15 "severe anxiety".

In March 2021, our clinic started an initiative to screen all patients for sleep apnea, depression, and anxiety as part of routine clinical care. STOP-BANG, PHQ-2, and GAD-7 
data were collected through a paper questionnaire that was completed by the patient prior to their appointment. These specific screening tools were chosen to standardize our questionnaires with those of other departments at our institution including Sleep Medicine. Patients were also asked to record their height and weight and whether they had a history of previously diagnosed OSA, depression, or anxiety. Additional demographical information including age, race, marital status, history of PCOS, and hypertension were collected by chart review.

\subsection{Analysis}

Routine descriptive statistics were used. Categorical variables were compared using $\mathrm{Chi}^{2}$ or Fishers exact testing. Continuous variables were compared using $t$-test or Wilcoxon rank sum as appropriate and presented as mean (standard deviation (SD)) or median (IQR (interquartile range)).

\section{Conclusions}

This study reports that in an academic fertility clinic, eight percent of women screened positive for obstructive sleep apnea. These women were also at increased risk for screening positive for depression and anxiety. Given the association between OSA and adverse pregnancy outcomes including fetal growth restriction, hypertensive disorders of pregnancy, and gestational diabetes mellitus, our results underline the need to screen women seeking fertility treatment.

Author Contributions: Conceptualization, L.G.C., K.M.A. and M.B.; methodology, L.M.B. and L.G.C.; software, L.M.B. and L.G.C.; validation, L.M.B. and L.G.C.; formal analysis, L.M.B. and L.G.C.; investigation, L.M.B. and L.G.C.; resources, L.M.B. and L.G.C.; data curation, L.M.B. and L.G.C.; writing-original draft preparation, L.M.B.; writing—review and editing, L.G.C., K.M.A. and M.B.; supervision, L.G.C.; project administration, L.M.B. and L.G.C. All authors have read and agreed to the published version of the manuscript.

Funding: This research received no external funding.

Institutional Review Board Statement: Ethical review and approval were waived for this study as it is a quality improvement project.

Informed Consent Statement: Not applicable.

Data Availability Statement: Primary data will be provided to any interested parties upon contact of the corresponding author.

Acknowledgments: This study was financially supported by the University of Wisconsin Departments of Obstetrics \& Gynecology. We thank Robert Koehler, medical librarian, for his assistance with literature review and procurement of articles.

Conflicts of Interest: The authors declare no conflict of interest.

\section{References}

1. Law, A.; McCoy, M.; Lynen, R.; Curkendall, S.M.; Gatwood, J.; Juneau, P.L.; Landsman-Blumberg, P. The prevalence of complications and healthcare costs during pregnancy. J. Med. Econ. 2015, 18, 533-541. [CrossRef] [PubMed]

2. Dempsey, J.A.; Veasey, S.C.; Morgan, B.J.; O’Donnell, C.P. Pathophysiology of sleep apnea. Physiol. Rev. 2010, 90, 47-112. [CrossRef] [PubMed]

3. Botros, N.; Concato, J.; Mohsenin, V.; Selim, B.; Doctor, K.; Yaggi, H.K. Obstructive sleep apnea as a risk factor for type 2 diabetes. Am. J. Med. 2009, 122, 1122-1127. [CrossRef] [PubMed]

4. Celen, Y.T.; Hedner, J.; Carlson, J.; Peker, Y. Impact of gender on incident diabetes mellitus in obstructive sleep apnea: A 16-year follow-up. J. Clin. Sleep Med. 2010, 6, 244-250. [CrossRef]

5. Kendzerska, T.; Gershon, A.S.; Hawker, G.; Tomlinson, G.; Leung, R.S. Obstructive sleep apnea and incident diabetes. A historical cohort study. Am. J. Respir. Crit. Care Med. 2014, 190, 218-225. [CrossRef]

6. Altaf, Q.A.; Dodson, P.; Ali, A.; Raymond, N.T.; Wharton, H.; Fellows, H.; Hampshire-Bancroft, R.; Shah, M.; Shepherd, E.; Miah, J.; et al. Obstructive Sleep Apnea and Retinopathy in Patients with Type 2 Diabetes. A Longitudinal Study. Am. J. Respir. Crit. Care Med. 2017, 196, 892-900. [CrossRef]

7. Bradley, T.D.; Floras, J.S. Obstructive sleep apnoea and its cardiovascular consequences. Lancet 2009, 373, 82-93. [CrossRef] 
8. Friedman, O.; Logan, A.G. The price of obstructive sleep apnea-hypopnea: Hypertension and other ill effects. J. Hypertens. 2009, 22, 474-483. [CrossRef]

9. Peppard, P.E.; Young, T.; Palta, M.; Skatrud, J. Prospective study of the association between sleep-disordered breathing and hypertension. N. Engl. J. Med. 2000, 342, 1378-1384. [CrossRef]

10. Gottlieb, D.J.; Yenokyan, G.; Newman, A.B.; O'Connor, G.T.; Punjabi, N.M.; Quan, S.F.; Redline, S.; Resnick, H.E.; Tong, E.K.; Diener-West, M.; et al. Prospective study of obstructive sleep apnea and incident coronary heart disease and heart failure: The sleep heart health study. Circulation 2010, 122, 352-360. [CrossRef]

11. Marin, J.M.; Carrizo, S.J.; Vicente, E.; Agusti, A.G.N. Long-term cardiovascular outcomes in men with obstructive sleep apnoeahypopnoea with or without treatment with continuous positive airway pressure: An observational study. Lancet 2005, 365, 1046-1053. [CrossRef]

12. Wheaton, A.G.; Perry, G.S.; Chapman, D.P.; Croft, J.B. Sleep disordered breathing and depression among U.S. adults: National Health and Nutrition Examination Survey, 2005-2008. Sleep 2012, 35, 461-467. [CrossRef] [PubMed]

13. Liu, L.; Kang, R.; Zhao, S.; Zhang, T.; Zhu, W.; Li, E.; Li, F.; Wan, S.; Zhao, Z. Sexual Dysfunction in Patients with Obstructive Sleep Apnea: A Systematic Review and Meta-Analysis. J. Sex. Med. 2015, 12, 1992-2003. [CrossRef] [PubMed]

14. Pinto, J.A.; Ribeiro, D.K.; Cavallini, A.F.D.S.; Duarte, C.; Freitas, G.S. Comorbidities Associated with Obstructive Sleep Apnea: A Retrospective Study. Int. Arch. Otorhinolaryngol. 2016, 20, 145-150. [CrossRef]

15. Gilat, H.; Vinker, S.; Buda, I.; Soudry, E.; Shani, M.; Bachar, G. Obstructive sleep apnea and cardiovascular comorbidities: A large epidemiologic study. Medicine 2014, 93, e45. [CrossRef]

16. Chen, Y.-H.; Keller, J.K.; Kang, J.-H.; Hsieh, H.-J.; Lin, H.-C. Obstructive sleep apnea and the subsequent risk of depressive disorder: A population-based follow-up study. J. Clin. Sleep Med. 2013, 9, 417-423. [CrossRef]

17. Pamidi, S.; Kimoff, R.J. Maternal Sleep-Disordered Breathing. Chest 2018, 153, 1052-1066. [CrossRef]

18. Young, T.; Palta, M.; Dempsey, J.; Skatrud, J.; Weber, S.; Badr, S. The occurrence of sleep-disordered breathing among middle-aged adults. N. Engl. J. Med. 1993, 328, 1230-1235. [CrossRef]

19. Louis, J.M.; Koch, M.A.; Reddy, U.M.; Silver, R.M.; Parker, C.B.; Facco, F.L.; Redline, S.; Nhan-Chang, C.-L.; Chung, J.H.; Pien, G.W.; et al. Predictors of sleep-disordered breathing in pregnancy. Am. J. Obstet. Gynecol. 2018, 218, 521.e1-521.e12. [CrossRef]

20. Facco, F.L.; Parker, C.B.; Reddy, U.M.; Silver, R.M.; Koch, M.A.; Louis, J.M.; Basner, R.C.; Chung, J.H.; Nhan-Chang, C.-L.; Pien, G.W.; et al. Association Between Sleep-Disordered Breathing and Hypertensive Disorders of Pregnancy and Gestational Diabetes Mellitus. Obstet. Gynecol. 2017, 129, 31-41. [CrossRef]

21. Pien, G.W.; Schwab, R.J. Sleep disorders during pregnancy. Sleep 2004, 27, 1405-1417. [CrossRef] [PubMed]

22. Yinon, D.; Lowenstein, L.; Suraya, S.; Beloosesky, R.; Zmora, O.; Malhotra, A.; Pillar, G. Pre-eclampsia is associated with sleep-disordered breathing and endothelial dysfunction. Eur. Respir. J. 2006, 27, 328-333. [CrossRef] [PubMed]

23. Bazalakova, M. Sleep Disorders in Pregnancy. Semin. Neurol. 2017, 37, 661-668. [CrossRef] [PubMed]

24. Sahin, F.K.; Koken, G.; Cosar, E.; Saylan, F.; Fidan, F.; Yilmazer, M.; Unlu, M. Obstructive sleep apnea in pregnancy and fetal outcome. Int. J. Gynecol. Obstet. 2008, 100, 141-146. [CrossRef]

25. Pilkington, S.; Carli, F.; Dakin, M.J.; Romney, M.; De Witt, K.A.; Doré, C.J.; Cormack, R.S. Increase in Mallampati score during pregnancy. Br. J. Anaesth. 1995, 74, 638-642. [CrossRef] [PubMed]

26. Olivarez, S.A.; Ferres, M.; Antony, K.; Mattewal, A.; Maheshwari, B.; Sangi-Haghpeykar, H.; Aagaard-Tillery, K. Obstructive sleep apnea screening in pregnancy, perinatal outcomes, and impact of maternal obesity. Am. J. Perinatol. 2011, 28, 651-658. [CrossRef]

27. Izci, B.; Riha, R.L.; Martin, S.E.; Vennelle, M.; Liston, W.A.; Dundas, K.C.; Calder, A.A.; Douglas, N.J. The upper airway in pregnancy and pre-eclampsia. Am. J. Respir. Crit. Care Med. 2003, 167, 137-140. [CrossRef]

28. Antony, K.M.; Agrawal, A.; Arndt, M.E.; Murphy, A.M.; Alapat, P.M.; Guntupalli, K.K.; Aagaard, K.M. Association of adverse perinatal outcomes with screening measures of obstructive sleep apnea. J. Perinatol. 2014, 34, 441-448. [CrossRef]

29. Jelic, S.; Le Jemtel, T.H. Inflammation, oxidative stress, and the vascular endothelium in obstructive sleep apnea. Trends Cardiovasc. Med. 2008, 18, 253-260. [CrossRef]

30. Romero, R.; Badr, M.S. A role for sleep disorders in pregnancy complications: Challenges and opportunities. Am. J. Obstet. Gynecol. 2014, 210, 3-11. [CrossRef]

31. Rodgers, G.M.; Taylor, R.N.; Roberts, J.M. Preeclampsia is associated with a serum factor cytotoxic to human endothelial cells. Am. J. Obstet. Gynecol. 1988, 159, 908-914. [CrossRef]

32. Roberts, J.M.; Taylor, R.N.; Musci, T.J.; Rodgers, G.M.; Hubel, C.A.; McLaughlin, M.K. Preeclampsia: An endothelial cell disorder. Am. J. Obstet. Gynecol. 1989, 161, 1200-1204. [CrossRef]

33. Sacks, G.P.; Studena, K.; Sargent, K.; Redman, C.W. Normal pregnancy and preeclampsia both produce inflammatory changes in peripheral blood leukocytes akin to those of sepsis. Am. J. Obstet. Gynecol. 1998, 179, 80-86. [CrossRef]

34. Cai, C.; Vandermeer, B.; Khurana, R.; Nerenberg, K.; Featherstone, R.; Sebastianski, M.; Davenport, M.H. The impact of occupational shift work and working hours during pregnancy on health outcomes: A systematic review and meta-analysis. Am. J. Obstet. Gynecol. 2019, 221, 563-576. [CrossRef]

35. Bonzini, M.; Palmer, K.T.; Coggon, D.; Carugno, M.; Cromi, A.; Ferrario, M.M. Shift work and pregnancy outcomes: A systematic review with meta-analysis of currently available epidemiological studies. BJOG Int. J. Obstet. Gynaecol. 2011, 118, 1429-1437. [CrossRef] 
36. Eisenberg, E.; Legro, R.S.; Diamond, M.P.; Huang, H.; O’Brien, L.M.; Smith, Y.R.; Coutifaris, C.; Hansen, K.R.; Santoro, N.; Zhang, H. Sleep Habits of Women with Infertility. J. Clin. Endocrinol. Metab. 2021, 106, e4414-e4426. [CrossRef]

37. Bonsignore, M.R.; Saaresranta, T.; Riha, R.L. Sex differences in obstructive sleep apnoea. Eur. Respir. Rev. 2019, $28,190030$. [CrossRef]

38. Quintana-Gallego, E.; Carmona-Bernal, C.; Capote, F.; Sánchez-Armengol, A.; Botebol-Benhamou, G.; Polo-Padillo, J.; CastilloGómez, J. Gender differences in obstructive sleep apnea syndrome: A clinical study of 1166 patients. Respir. Med. 2004, 98, 984-989. [CrossRef]

39. Wimms, A.; Woehrle, H.; Ketheeswaran, S.; Ramanan, D.; Armitstead, J. Obstructive Sleep Apnea in Women: Specific Issues and Interventions. BioMed Res. Int. 2016, 2016, 1764837. [CrossRef]

40. Khalid, F.; Ayache, M.; Auckley, D. The differential impact of respiratory event scoring criteria on CPAP eligibility in women and men. J. Clin. Sleep Med. 2021, 17, 2409-2414. [CrossRef]

41. Jehan, S.; Auguste, E.; Pandi-Perumal, S.R.; Kalinowski, J.; Myers, A.K.; Zizi, F.; Rajanna, M.G.; Jean-Louis, G.; McFarlane, S.I. Depression, Obstructive Sleep Apnea and Psychosocial Health. Sleep Med. Disord. Int. J. 2017, 1, 12.

42. Ejaz, S.M.; Khawaja, I.S.; Bhatia, S.; Hurwitz, T.D. Obstructive sleep apnea and depression: A review. Innov. Clin. Neurosci. 2011, 8, 17-25. [PubMed]

43. Aro, M.M.; Anttalainen, U.; Polo, O.; Saaresranta, T. Mood, sleepiness, and weight gain after three years on CPAP therapy for sleep apnoea. Eur. Clin. Respir. J. 2021, 8, 1888394. [CrossRef] [PubMed]

44. Kiani, Z.; Simbar, M.; Hajian, S.; Zayeri, F. The prevalence of depression symptoms among infertile women: A systematic review and meta-analysis. Fertil. Res. Pract. 2021, 7, 6. [CrossRef] [PubMed]

45. Kiani, Z.; Simbar, M.; Hajian, S.; Zayeri, F.; Shahidi, M.; Saei Ghare Naz, M.; Ghasemi, V. The prevalence of anxiety symptoms in infertile women: A systematic review and meta-analysis. Fertil. Res. Pract. 2020, 6, 7. [CrossRef]

46. Lawson, A.K.; Klock, S.C.; Pavone, M.E.; Hirshfeld-Cytron, J.; Smith, K.N.; Kazer, R.R. Prospective study of depression and anxiety in female fertility preservation and infertility patients. Fertil. Steril. 2014, 102, 1377-1384. [CrossRef]

47. Rooney, K.L.; Domar, A.D. The relationship between stress and infertility. Dialogues Clin. Neurosci. 2018, 20, 41-47. [CrossRef]

48. Helvaci, N.; Karabulut, E.; Demir, A.U.; Yildiz, B.O. Polycystic ovary syndrome and the risk of obstructive sleep apnea: A meta-analysis and review of the literature. Endocr. Connect. 2017, 6, 437-445. [CrossRef]

49. Obesity and reproduction: A committee opinion. Fertil. Steril. 2015, 104, 1116-1126. [CrossRef]

50. Mutsaerts, M.A.Q.; van Oers, A.M.; Groen, H.; Burggraaff, J.M.; Kuchenbecker, W.K.H.; Perquin, D.A.M.; Koks, C.A.M.; van Golde, R.; Kaaijk, E.M.; Schierbeek, J.M.; et al. Randomized Trial of a Lifestyle Program in Obese Infertile Women. N. Engl. J. Med. 2016, 374, 1942-1953. [CrossRef]

51. Einarsson, S.; Bergh, C.; Friberg, B.; Pinborg, A.; Klajnbard, A.; Karlström, P.-O.; Kluge, L.; Larsson, I.; Loft, A.; Mikkelsen-Englund, A.-L.; et al. Weight reduction intervention for obese infertile women prior to IVF: A randomized controlled trial. Hum. Reprod. 2017, 32, 1621-1630. [CrossRef] [PubMed]

52. Legro, R.S.; Dodson, W.C.; Kunselman, A.R.; Stetter, C.M.; Kris-Etherton, P.M.; Williams, N.I.; Gnatuk, C.L.; Estes, S.J.; Allison, K.C.; Sarwer, D.B.; et al. Benefit of Delayed Fertility Therapy with Preconception Weight Loss Over Immediate Therapy in Obese Women with PCOS. J. Clin. Endocrinol. Metab. 2016, 101, 2658-2666. [CrossRef]

53. Legro, R.S.; Dodson, W.C.; Kris-Etherton, P.M.; Kunselman, A.R.; Stetter, C.M.; Williams, N.I.; Gnatuk, C.L.; Estes, S.J.; Fleming, J.; Allison, K.C.; et al. Randomized Controlled Trial of Preconception Interventions in Infertile Women with Polycystic Ovary Syndrome. J. Clin. Endocrinol. Metab. 2015, 100, 4048-4058. [CrossRef] [PubMed]

54. Chung, F.; Yegneswaran, B.; Liao, P.; Chung, S.A.; Vairavanathan, S.; Islam, S.; Khajehdehi, A.; Shapiro, C.M. STOP questionnaire: A tool to screen patients for obstructive sleep apnea. Anesthesiology 2008, 108, 812-821. [CrossRef] [PubMed] 